\title{
Note on Editions of Texts
}

It is necessary to say a few words about the editions of the main medieval treatises of Scots law which have been used in this book. The two principal works are Regiam Majestatem and Quoniam Attachiamenta. Until recently, there was no satisfactory critical edition of either text. Sir John Skene published versions in Latin and Scots in 1609, both of which have been subjected to severe criticism (some of it perhaps a little unfair) ever since. In the nineteenth century, Cosmo Innes and Thomas Thomson published another edition of the Latin texts in the first volume of the Acts of the Parliaments of Scotland. Subsequent scholarship has shown these editions also to be defective in various ways. In 1947, the Stair Society published further texts under the editorship of Lord Cooper. Unfortunately, these were based on the work of Skene, although Lord Cooper provided cross-references to the APS edition along with translations. Very recently, an authoritative critical edition of Quoniam was at last produced, by Dr David Fergus of Glasgow University in his doctoral thesis, but this has not yet been published (it is hoped, however, that the work will become a Stair Society publication in due course).

Accordingly, in citing and discussing Quoniam, Dr Fergus' text has been used; it is cited as $Q A$ (Fergus). Because it is not yet published, I have decided to give references also to the $A P S$ and Cooper editions, citing them as $Q A$ (APS) and $Q A$ (Cooper) respectively. In the absence of an authoritative version of Regiam, I have chosen again to use and cite both the APS and Cooper texts, citing them as RM (APS) and RM (Cooper) respectively. As a result, the interested reader who consults the relevant footnote references will quickly perceive some of the basic problems which have bedevilled the use of the texts of medieval Scots law. Regiam is cited by book and chapter numbers, Quoniam by chapter numbers alone.

It is at present generally accepted that the English works known as Glanvill and Bracton were not written by their eponyms, but I have nonetheless continued to speak as though they had been, indicating that this is not the case by italicising the names. It may also be worth 
mentioning that Bracton is now thought to be mainly a work of the $1220 \mathrm{~s}$. Glanvill is cited by book and chapter number in the most recent edition by G. D. G. Hall, and Bracton by foliation, although references to the volume and page numbers of the most recent (four volume) edition by S. E. Thorne have been added for convenience. 